\title{
Collective proceedings in the Competition Appeal Tribunal: taking stock and looking ahead
}

\author{
Ricky Versteeg ${ }^{*}$ and Alexandra Malina ${ }^{\dagger}$
}

\begin{abstract}
A new collective actions regime for competition damages claims was introduced in the UK in 2015 . Although seven proposed collective proceedings have been brought since that time, none have, as yet, continued beyond the certification stage, and no further cases are likely to proceed to a full certification hearing pending an appeal to the Supreme Court in the Merricks v Mastercard proceedings in 2020. It is, therefore, an opportune time to take stock of the new regime. This article explores the development of the regime to date, considers what lies ahead, and assesses the overall status and progress of the regime. It is suggested that the forthcoming Supreme Court appeal in Merricks provides a welcome opportunity both to build on the significant progress that has already been made on a number of key aspects of the new procedure over the past four years, and to redress some of the legal and policy implications of the recent Court of Appeal judgment in the Merricks proceedings, which risk undermining the important 'gatekeeping' function afforded to the Competition Appeal Tribunal under the legislation. The UK collective proceedings regime ought then to be on a strong footing to resume, albeit its development will remain necessarily iterative and cumulative as further important aspects of the new regime are considered by the CAT and appellate courts over the coming years.
\end{abstract}

Keywords: collective proceedings, collective proceedings order, class action, certification, Merricks $v$ Mastercard, Competition Appeal Tribunal, Consumer Rights Act 2015

\section{Introduction}

Ever since the new collective actions regime for competition law damages claims took effect in the UK in October 2015, there has been speculation about the extent to which that new regime is, or will likely become, an established part of the litigation and competition law landscape in the UK.

Senior Associate, Freshfields Bruckhaus Deringer LLP, London.

Associate, Freshfields Bruckhaus Deringer LLP, London.

This article is based on a presentation made by Ricky Versteeg at the 12th Annual Junior Competition Conference held on 10 May 2019. Freshfields Bruckhaus Deringer LLP is advising Mastercard in the Merricks $v$ Mastercard case that is considered in this article. Freshfields also acts for clients objecting to the proposed Trucks and Rail Fares collective proceedings referred to in this article. All views expressed in this article are personal to the authors.

1 Case No. 1257/7/7/16 Dorothy Gibson v Pride Mobility Products Limited ('Mobility Scooters'). See https://www.catribunal.org.uk/cases/12577716dorothy-gibson.

2 Case No. 1266/7/7/16 Walter Hugh Merricks CBE v Mastercard Incorporated and Others ('Merricks'). See https://www.catribunal.org.uk/cases/ 12667716-walter-hugh-merricks-cbe.

3 Case No. 1282/7/7/18 UK Trucks Claim Limited v Fiat Chrysler Automobiles N.V. and Others; and Case No. 1289/7/7/18 Road Haulage Association Limited $v$ MAN SE and Others (together, 'Trucks'). See https://
In that time, seven proposed collective proceedings have been brought, concerning mobility scooters, ${ }^{1}$ interchange fees, ${ }^{2}$ trucks, ${ }^{3}$ rail fares, ${ }^{4}$ and foreign exchange fees. ${ }^{5}$ They have alleged or sought to follow-on from findings of vertical, ${ }^{6}$ horizontal, ${ }^{7}$ and abuse of dominance infringements. ${ }^{8}$ Proposed class representatives have included individuals, ${ }^{9}$ an industry body, ${ }^{10}$ and special purpose www.catribunal.org.uk/cases/12827718-uk-trucks-claim-limited and https://www.catribunal.org.uk/cases/12897718-road-haulage-associationlimited, respectively.

4 Case No. 1304/7/7/19 Justin Gutmann v First MTR South Western Trains Limited and Another; and Case No. 1305/7/7/19 Justin Gutmann v London \& South Eastern Railway Limited (together, 'Rail Fares'). See https://www. catribunal.org.uk/cases/13047719-justin-gutmann and https://www.catribunal.org.uk/cases/13057719-justin-gutmann, respectively.

5 Case No. 1329/7/7/19 Michael O'Higgins FX Class Representative Limited v Barclays Bank PLC and Others ("Forex"). See https://www.catribunal.org. $\mathrm{uk} /$ cases/13297719-michael-ohiggins-fx-class-representative-limited.

6 See Mobility Scooters (fn 1).

7 See Merricks (fn 2) and Trucks (fn 3).

8 See Rail Fares (fn 4).

9 Dorothy Gibson in Mobility Scooters (fn 1); Walter Hugh Merricks CBE in Merricks (fn 2); and Justin Gutmann in Rail Fares (fn 4).

10 The Road Haulage Association in Trucks (fn 3). 
litigation vehicles. ${ }^{11}$ At least four different third party litigation funders have funded those proposed proceedings. ${ }^{12}$ The appetite of proposed class representatives, law firms and third party funders to make use of the new collective proceedings regime, in respect of a broad range of actual or alleged infringements of UK and/or EU competition law, has therefore been clear, notwithstanding any initial legal uncertainty about how the regime would operate.

None of those proposed collective proceedings have yet, however, continued beyond the certification stage. The reasons for this are varied and case-specific. The first proposed action to be brought under the new regime, Mobility Scooters, concerned a relatively low-value claim and a limited vertical infringement, and was voluntarily discontinued after certification was initially refused by the Competition Appeal Tribunal (the 'CAT'). ${ }^{13}$ By contrast, the second proposed action to be brought under the regime, Merricks, was reportedly the largest civil claim ever brought in the UK and was breathtakingly broad in personal, material and temporal scope. Certification of that action was initially refused by the CAT, ${ }^{14}$ but certain points of law will reach the Supreme Court, on appeal from the Court of Appeal (which overturned the CAT's refusal) ${ }^{15}$ next year. ${ }^{16}$ None of the other proposed collective proceedings, which are at an earlier stage, are likely to proceed to a full certification hearing pending the outcome of Mastercard's appeal to the Supreme Court in Merricks. ${ }^{17}$

It is, therefore, an opportune time to take stock of the regime that was introduced in 2015. It is suggested that for a regime that was intended to introduce an effective mechanism for collective private redress without opening the floodgates to a US-style class action culture, the number and diversity of proposed actions that have been brought in the first four years might be about the same as (and certainly no fewer than) what was expected by the government and lawmakers. Significant progress has been made, and greater clarity has been achieved, on a number of key aspects of the new legal and procedural framework. And the Supreme Court will, next year, provide authoritative guidance on the legal framework for certification that will apply to all future actions. That represents, in the authors' view, a great deal of progress for a regime that

11 UK Trucks Claim Limited in Trucks (fn 3); and Michael O'Higgins FX Class Representative Limited in Forex (fn 5) (albeit Mr Higgins himself is also experienced in the field of financial services).

12 See e.g. formerly Burford Capital and currently Innsworth Litigation Funding in Merricks (fn 2); and Therium Capital and Calunius Capital in Trucks (fn 3).

13 Dorothy Gibson v Pride Mobility Products Limited [2017] CAT 9.

14 Walter Hugh Merricks CBE v Mastercard [2017] CAT 16.

15 Walter Hugh Merricks CBE v Mastercard [2019] EWCA Civ 674.

16 See e.g. 'Mastercard to fight $£ 14 \mathrm{bn}$ legal case in Supreme Court', The Telegraph (26 July 2019), available at: https://www.telegraph.co.uk/business/ remains in its infancy, and for which it is critical that the first case (or cases) that proceed beyond certification are suitable and appropriate and will therefore instil public confidence in the new regime. For the same reason, it is suggested that any inference that the certification framework set out by the CAT in Mobility Scooters and Merricks has unduly stunted the growth and development of the new regime is, at least, premature, and is likely also to be misconceived for the reasons considered in further detail in this article.

This article explores the current state of the regime and what lies ahead. In particular, Section 2 outlines the progress made to date, suggesting that there are several areas in relation to which parties and practitioners now have a greater degree of clarity and predictability. Section 3 analyzes the Court of Appeal's judgment (and Mastercard's forthcoming appeal to the Supreme Court) in Merricks regarding fundamental aspects of the certification procedure. Section 4 then takes stock of the current status of the regime, before some concluding remarks are provided in Section 5.

\section{Progress to date}

The case law and practice of the CAT in the proposed collective proceedings brought to date has provided a degree of clarity and predictability about a number of critical aspects of the certification process. It is suggested that those areas of progress, which are summarized in this section, ought to be welcomed by practitioners and together provide an excellent foundation upon which the regime can further develop following the Supreme Court judgment in Merricks (which is considered in further detail in Section 3).

\subsection{Certification timetable}

Although the CAT is unlikely to make any further certification decisions pending the judgment of the Supreme Court in Merricks, its practice to date provides practitioners with a useful indication of potential timeframes for the certification procedure once it resumes hearing and giving judgment on applications for certification.

2019/07/26/mastercard-fight-14bn-legal-case-supreme-court/. The basis on which the Supreme Court granted permission to appeal has not yet been published on its website.

17 See e.g. the CAT's reasoned order for adjourning the joint certification hearing in Trucks: UK Trucks Claim Limited v Fiat Chrysler Automobiles N.V. and others and Road Haulage Association Limited $v$ MAN SE and Others [2017] CAT 15. Note that in June 2019, the CAT considered the proposed class representatives' funding arrangements in Trucks, as those issues were not considered by the CAT to be affected by the issues to be considered by the Supreme Court in Merricks. A judgment by the $\mathrm{CAT}$ on those preliminary funding issues is pending at the time of writing. 
The duration of the certification process will depend on a range of factors. ${ }^{18}$ At a high level, however, the first case management conference in the actions proposed to date has tended to take place within approximately three months of the collective proceedings claim form being filed with the CAT. ${ }^{19}$ In the most recent Trucks and Rail Fares proceedings, the hearings of the applications for certification were then scheduled to take place within approximately six months of the first case management conference. ${ }^{20}$ This suggests that a certification hearing might typically take place within around nine to 12 months of the collective proceedings claim form originally being filed. $^{21}$

Only time will tell whether, once the regime resumes following the Supreme Court's judgment in Merricks, the CAT will feel able to condense those timeframes to reflect its (and the parties' and their advisers') growing experience in the area and to take account of the procedural implications of any guidance provided by the Supreme Court.

\subsection{Interested parties and interveners}

The CAT Rules 2015 provide mechanisms whereby class members and any other 'person with an interest' can participate in the certification process. ${ }^{22}$ They also contain provisions that apply to all proceedings in the CAT whereby parties with a 'sufficient interest' in the outcome may apply to intervene in those proceedings. ${ }^{23}$

The two Trucks actions were the first proposed collective proceedings to concern a number of jointly and severally liable parties to an infringement that were not all

18 These factors include, for example: the number of parties; the complexity of the issues arising at certification; the availability of the CAT for case management conference(s) and a certification hearing; and any delays associated with procedural issues (such as transparency of funding arrangements and potential applications for pre-action disclosure: see sections 2.3 and 2.4 below).

19 Competition Appeal Tribunal Rules 2015 (the 'CAT Rules 2015'), Rule 76(9) provide that a case management conference shall be held '[a]s soon as practicable' to give directions in relation to the application for a collective proceedings order.

20 The overall time periods were shorter in Mobility Scooters and Merricks, which were procedurally atypical cases with fewer parties. Although in Mobility Scooters the CAT observed that the UK regime is intended to have short certification hearings held within months of the collective proceedings claim form being served (see Dorothy Gibson v Pride Mobility Products (fn 13), para 104), subsequent practice in Trucks and Rail Fares has suggested that such expectations are likely to have been optimistic, at least in complex and multi-party proceedings while the regime remains at a formative stage.

21 A further period will then be required for any judgment from the CAT (in Mobility Scooters and Merricks, certification judgments were issued by the CAT within approximately four and six months of the certification hearings, respectively) and any potential appeals (see Section 2.7 below).

22 CAT Rules 2015, Rule 76(10)(c). named as defendants. ${ }^{24}$ In those circumstances, it was unclear whether the jointly and severally liable parties that were not named as defendants could participate fully in the certification process by way of the 'interested party' mechanism set out in the CAT Rules 2015, or if they should instead seek to intervene in the proposed collective proceedings in order to secure their right to full participation at certification. ${ }^{25}$

The CAT considered this issue in Trucks and decided that the 'interested party' route was the appropriate mechanism at the certification stage. However, this decision was expressly made on the basis that there would be no practical difference in those proceedings between a jointly and severally liable party being an 'interested party' as opposed to an 'intervener'. In particular, the CAT clarified that the joint and severally liable interested parties in Trucks would have the right to adduce their own non-duplicative factual and/or expert evidence and make submissions beyond mere 'objections' at the certification stage. ${ }^{26}$ This approach is likely to be adopted by the CAT in future cases.

\subsection{Transparency and scrutiny of funding arrangements}

The CAT has, to date, required significant transparency of the funding arrangements of the proposed class representatives at the certification stage. Although the CAT has indicated that it might allow the most sensitive information about case strategy and other privileged material to be withheld, it has also made clear that any proposed redactions on those grounds will be subject to a line-byline assessment, and that wholesale redactions of entire

23 CAT Rules 2015, Rule 16(1), which applies to collective proceedings pursuant to CAT Rules 2015, Rules 74(1) and 50(1).

24 Jointly and severally liable parties that are not named as defendants to competition damages proceedings are often joined to those proceedings by way of 'contribution' claims brought by the main defendants: see e.g. CAT Rules 2015, Rule 39; Civil Liability (Contribution) Act 1978, s 1. However, it is unlikely to be possible (without permission of the CAT) for contribution claims to be brought against third parties at the certification stage of collective proceedings under the CAT Rules 2015: see e.g. Rule 39(3)(b) (which provides that a contribution claim can only be filed with the CAT's permission unless filed alongside a defence) and Rule 76(11) (which provides that a defendant does not need to file a defence before the hearing of an application for a collective proceedings order). In the event that collective proceedings are certified, contribution claims will be able to be brought in the normal way against any jointly and severally liable parties who are not named as main defendants.

25 See, in particular, the provision for the participation of parties 'with an interest' in CAT Rules 2015, Rule 76(10)(c), appears, on its face, to be limited to those interested parties 'objecting' to the application, rather than making more fulsome submissions or observations or submitting supporting evidence.

26 See e.g. the transcript of the December 2018 case management hearing in the Trucks actions (available at https://www.catribunal.org.uk/sites/ default/files/2019-01/1282-1289_Trucks_Transcript_121218_1.pdf), p 24, lines 9-19. 
pages or sections of the funding arrangements are unlikely to be acceptable. ${ }^{27}$ In those circumstances, and particularly if the proposed class representative is seeking to obtain certification as quickly as possible, it may well be in the representative's interest to be as transparent as possible regarding the funding arrangements from the outset (subject, of course, to appropriately robust confidentiality ring arrangements being put in place) in order to avoid satellite disputes on the matter.

Having insisted on such transparency, the CAT has demonstrated considerable flexibility in its substantive assessment of proposed funding arrangements. In Merricks, for example, the CAT considered (and allowed, in principle) funding arrangements whereby the funder would have been paid a potentially extremely large return out of unclaimed damages, without close scrutiny of the underlying governance, interests and affairs of the funder or its relationship with the proposed class representative beyond the relevant contractual arrangements. ${ }^{28}$ The CAT is also currently considering, in the Trucks proceedings, proposed funding arrangements whereby the funders are paid a proportion of any damages awarded to the class members. ${ }^{29}$ In those cases to date, the CAT has tended to focus on points of detail regarding the drafting, clarity, operability and enforceability of the relevant contractual provisions. ${ }^{30}$ It has also shown a willingness to keep under review, and if necessary revisit, certain issues, such as the sufficiency of any adverse costs cover during the course of the proceedings. ${ }^{31}$

Although issues regarding the potential need for closer substantive scrutiny of funders and funding arrangements, including possible formal regulation of third party litigation funders in the UK, are highly topical, detailed consideration of them is beyond the scope of this article. ${ }^{32}$ That said, it is the authors' view that the CAT's relatively permissive approach to funding matters to date only reinforces the need for the certification stage of the collective proceedings regime to act as a meaningful filter of proposed actions (as discussed in further detail in Section 3 below). In particular, it is submitted that a permissive approach to funding arrangements, combined with a low standard for certification, could be a recipe for a speculative class action culture that is very different to the one originally envisaged by the UK Government and lawmakers and contrary to the underlying policy objectives of the new regime (which included a desire to avoid the excesses of US class action culture).

\subsection{Applications for pre-certification disclosure}

The CAT Rules 2015 provide for the possibility of limited disclosure at the certification stage. ${ }^{33}$ In practice, however, disclosure applications have not been a significant feature of the proposed collective proceedings brought to date, and this is unlikely to change in the future. Certainly, the CAT has and will be prepared to allow specific and proportionate requests for information or documents that are directly relevant to the issues on certification (e.g. regarding class composition and membership). However, the CAT will not allow broad disclosure requests or 'fishing expeditions' at the certification stage. This is especially so in light of the need for the CAT to avoid conducting a 'mini trial' at certification, ${ }^{34}$ an issue that will be considered by the Supreme Court in Merricks (see Section 2.5 and Section 3 below).
27 See e.g. the transcript of the December 2018 case management hearing in the Trucks actions (fn 26), at p 20, lines 3-10.

28 Walter Hugh Merricks CBE v Mastercard (CAT) (fn 14), paras 92-140. In support of its approach, the CAT referred, amongst other things, to 'the purpose of the [Consumer Rights Act 2015] and the new collective proceedings regime', and to the House of Lords debate on 3 November 2014 which made it clear that the Government 'envisaged that many collective actions would be dependent on third party funding': see paras 125-127.

29 As noted above (fn 17), in June 2019 the CAT considered the proposed class representatives' funding arrangements in Trucks. A judgment by the CAT on those preliminary issues is pending at the time of writing. One of the challenges raised against the funding arrangements in place in Trucks is that they amount to damages based agreements ('DBAs'), which are unenforceable insofar as they relate to opt-out collective proceedings (see the Competition Act 1998 ('CA 1998'), s 47C(8)) and which must comply with the Damages-Based Agreement Regulations 2013 in order to be enforceable in respect of opt-in collective proceedings.

30 See e.g. Walter Hugh Merricks CBE v Mastercard (CAT) (fn 14), paras 92-140.

31 Walter Hugh Merricks CBE v Mastercard (CAT) (fn 14), para 131.

32 For further detail on this topic, see e.g. Perrin, 'England and Wales', The Third Party Litigation Funding Law Review (Edition 2, December 2018), available at https://thelawreviews.co.uk/edition/the-third-party-litigation- funding-law-review-edition-2/1176821/england-and-wales; and MaceyDare, '3rd Party Litigation Funding Agreements, Damages Misallocation Risk, and Class Action Transparency' (23 May 2019), available at https://papers.ssrn.com/sol3/papers.cfm?abstract_id=3393002.

33 See CAT Rules 2015, Rules 53(2)(d) and 60. See also the Competition Appeal Tribunal's Guide to Proceedings 2015 (the 'CAT Guide 2015'), available at https://www.catribunal.org.uk/sites/default/files/2017-12/ guide_to_proceedings_2015.pdf, para 6.28; and Dorothy Gibson v Pride Mobility Products Limited (fn 13), para 104.

34 Walter Hugh Merricks CBE v Mastercard (CAT) (fn 14), para 57. In Rail Fares, for example, the CAT responded to a defendant's request for disclosure of (amongst other things) materials underpinning the claimants' expert analysis by stating that: ' $[\mathrm{I}] \mathrm{t}$ is not at the certification stage the appropriate place to pore over the data and see whether it might be argued that it points to a different outcome. We are concerned whether there is data there on which the methodology ... can be used, and whether it is a reasonable methodology. It is not a full-blown enquiry into the robustness of [the] report of anything like the kind you could mount if the proceedings are certified ...': see transcript of the April 2019 case management hearing in Rail Fares (available at https://www.catribunal. org.uk/sites/default/files/2019-04/1304-1305_Transcript_09042019.pdf), p 16, lines 2-9. 


\subsection{Conduct of the certification hearing}

The Court of Appeal in Merricks criticized the CAT for 'more or less' conducting a 'mini trial' at the certification stage. ${ }^{35}$ This finding was made notwithstanding that Mastercard did not adduce any expert evidence at the certification hearing, ${ }^{36}$ the Tribunal expressly directed itself not to conduct a 'mini-trial', ${ }^{37}$ and the certification hearing was limited to three days' duration. The Supreme Court's view of whether that did, in fact, amount to a mini-trial will have a significant influence on the length and conduct of future certification hearings, including as regards the role of experts and the treatment of factual and economic evidence at those hearings. Regardless of the Supreme Court's view, however, the conduct of the certification hearings before the CAT to date provides an insight into how the Tribunal may wish to approach such hearings in a relatively 'inquisitorial', as opposed to adversarial, manner in future. ${ }^{38}$

\subsection{Competing certification applications}

The Trucks proceedings are the first instance of a certification 'battle' between two proposed class representatives under the new UK regime, as frequently occurs in overseas class action regimes such as those in the US. ${ }^{39}$ The proposed classes and claims in each of the Trucks actions overlap significantly, but there are also a number of material differences. ${ }^{40}$ The CAT will therefore be called upon to give a view, at an early stage of the development of the new regime, on whether (at least in that case) there can, or should, be dual or overlapping class actions in respect of the same infringement ${ }^{41}$ and, if so, how that would operate in practice. The CAT will also need to consider and resolve complex case management issues at the certification stage itself when conducting joint certification hearings, as is proposed in the Trucks and Rail Fares actions.

\subsection{Rights of challenge to certification decision}

In Merricks, the Court of Appeal found that a right of appeal on a point of law existed from the CAT's refusal to certify the proposed collective action. ${ }^{42}$ The reasoning of the Court of Appeal was that the refusal to certify was a decision 'as to the award of damages' because it denies the proposed class representative the 'unique remedy' of an aggregate award of damages. ${ }^{43} \mathrm{~A}$ right of appeal on a point of law therefore exists under the legislation. ${ }^{44}$ This was different to the CAT's position (as reflected in the CAT Guide $2015^{45}$ and the CAT's understanding of the policy background ${ }^{46}$ ) that only judicial review is available in respect of the challenge of a certification decision. ${ }^{47}$

While the same grounds of review are likely to be available in an appeal on a point of law as in a judicial review, ${ }^{48}$ the relevant route taken will determine which Court hears the initial challenge and the number of
35 Walter Hugh Merricks CBE v Mastercard (Court of Appeal) (fn 15), para 52.

36 Walter Hugh Merricks CBE v Mastercard (CAT) (fn 14), para 5; and Walter Hugh Merricks CBE v Mastercard (Court of Appeal) (fn 15), para 26.

37 Walter Hugh Merricks CBE v Mastercard (CAT) (fn 14), para 57.

38 In particular, the CAT took an interactive approach to the certification hearings in Mobility Scooters (fn 1) and Merricks (fn 2), including direct questioning from the President and Panel Members of the CAT in keeping with its statutory obligation to be satisfied (by the proposed class representative) that the claims were suitable to proceed collectively. See e.g. the transcripts of the certification hearings in Mobility Scooters (available at https://www.catribunal.org.uk/cases/12577716-dorothy-gibson) and Merricks (available at https://www.catribunal.org.uk/cases/12667716-walterhugh-merricks-cbe).

39 See e.g. Wallerstein v. Dole Fresh Vegetables, Inc. 967 F. Supp. 2d 1289, 1293 (N.D. Cal. 2013); Keene v McKesson Corp., No. 12-CV-05924-JST, 2015 WL 9257949 (N.D. Cal. Dec. 17, 2015); and In re National Football League's 'Sunday Ticket' Antitrust Litig., 148 F. Supp. 3d 1358 (J.P.M.L. 2015).

40 There are, for example, significant overlaps between the two Trucks proceedings in respect of the proposed class definitions, asserted common issues, and certain funding issues that arise. There are, however, also material differences between the actions as regards the precise class boundaries and composition; whether the claims would be brought on an opt-out or opt-in basis; the proposed sub-classes; potential conflicts between class members; and the legal status of the proposed class representatives (amongst other things).

41 See e.g. CAT Rules 2015, Rule 78(2)(c).

42 Walter Hugh Merricks CBE v Mastercard [2018] EWCA Civ 2527.

43 Walter Hugh Merricks CBE v Mastercard (Court of Appeal) (fn 42), paras 27 and 29.
44 CA 1998, s 49(1A)(a).

45 CAT Guide 2015, para 6.92.

46 See e.g. Walter Hugh Merricks CBE v Mastercard [2017] CAT 21, para 16, where the CAT stated that: 'this approach of the legislation [i.e. that there is no appeal right in respect of a certification decision by the CAT] appears to reflect a deliberate policy. [...] In the attempt to craft an effective system of collective redress for the UK, the legislature has...sought to confine the right of appeal in collective proceedings to decisions on the substantive claims and preclude prolonged litigation in the process of approving the use of the collective procedure for the pursuit of those claims'.

47 Walter Hugh Merricks CBE v Mastercard (CAT) (fn 46), para 15.

48 See e.g. E $v$ Secretary of State for the Home Department [2004] EWCA Civ 49, para 42 (in which the Court of Appeal observed that 'the various procedures [i.e. appeal on a point of law and judicial review] have evolved to a point where it has become a generally safe working rule that the substantive grounds for intervention are identical ... [appeals on points of law] are treated as encompassing the traditional judicial review grounds of excess of power, irregularity and procedural irregularity'); Runa Begum $v$ Tower Hamlets London Borough Council [2003] UKHL 5, para 17 (in which the House of Lords held that 'an applicant [appealing on a point of law can] complain not only that the council misinterpreted the law but also of any illegality, procedural impropriety or irrationality which could be relied upon in proceedings for judicial review'); and Kruja $v$ Enfield London Borough Council [2005] HLR 13, para 21 (in which the Court of Appeal held that: 'Plainly, if the County Court conducting a statutory judicial review ... is confronted by a true case of perversity in the review decision that is an elementary error of law and the County Court has ample jurisdiction to correct it'). Also see generally, Fordham, Judicial Review Handbook (6th edn, Hart Publishing, 2012) paras 15.2 and 27.2.3. 
further appeals that may be available. ${ }^{49}$ The potential practical impact of there being a right of appeal, as opposed to only a right of judicial review, has been demonstrated in Merricks, which is already due to be considered by the Supreme Court in 2020 (see Section 3).

Some uncertainty also arguably remains as to the correct avenue of challenge that would apply where an aggregate award of damages is not sought in collective proceedings, ${ }^{50}$ or where a collective proceedings order is granted by the CAT. ${ }^{51}$

\section{Looking ahead to the Supreme Court appeal in Merricks}

The Merricks proceedings, brought in September 2016, remain the largest and most high profile of the proposed collective proceedings brought to date. The proposed class covers some 46 million UK consumers over a period of more than 16 years ending in 2008, leading to an asserted claim amount of around $£ 14$ billion. The proposed class is therefore incredibly broad and diffuse, even by the standards of established class action regimes such as those in the US. That breadth and diffusion caused considerable concern to the CAT and was an important factor in its decision to refuse certification in July 2017. That refusal has led, in turn, to the first consideration by UK appellate courts of aspects of the certification procedure under the new collective proceedings regime, which will culminate in Mastercard's appeal to the Supreme Court, which is likely to be heard during 2020. This section provides a short recap of the judgments of the CAT and Court of Appeal in Merricks, before briefly considering issues that will arise, to a greater or lesser extent, in the forthcoming Supreme Court appeal.

\subsection{Recap: CAT and Court of Appeal judgments in Merricks}

In July 2017, the CAT refused to certify the Merricks proceedings. ${ }^{52}$ This was for two reasons, each of which would have been sufficient on its own to require dismissal of the application. First, the CAT found that the claims were not suitable for an aggregate award of damages, ${ }^{53}$ because it was unpersuaded on the material put before it that there was sufficient data available for the proposed methodology for quantifying aggregate damages to be applied on a sufficiently sound basis. ${ }^{54}$ Secondly, the CAT found that the claims were not suitable to be brought collectively, ${ }^{55}$ because the proposed distribution method for any aggregate damages award to individual class members bore no relation to the principle of compensation and it was impossible, in this case, to see how payments to individuals could be determined on any reasonable basis. ${ }^{56}$

Two key broader concerns underpinned the CAT's decision. First, as regards data availability, the CAT was concerned that it would be impossible to assess (even on an average basis) the rate at which merchants had 'passed-on' any overcharge on interchange fees to their customers, given this was a claim relating to virtually the entire UK retail sector where different pass-on rates would apply between different sectors of the economy and between different businesses within those sectors,
49 In particular, a judicial review against a judgment of the CAT will be heard by the High Court of England and Wales (Administrative Court), with potential further appeals to the Court of Appeal and Supreme Court. An appeal on a point of law against a CAT judgment will be heard by the Court of Appeal, with a potential further appeal to the Supreme Court.

50 As in, e.g. the Trucks action brought by the Road Haulage Association (see fn 3 ).

51 See e.g. Enron Coal Services Ltd (in liquidation) v English Welsh \& Scottish Railway Ltd [2009] EWCA Civ 647. In that case, the parties were agreed that a decision to strike-out a follow-on claim under CA 1998, s 47A was a decision 'as to the award of damages' because it brought the proceedings to an end. In those circumstances, the Court of Appeal was asked to consider whether a decision not to strike-out part of a follow-on claim would also be a decision 'as to the award of damages' such that a right of appeal existed under the legislation. The Court of Appeal held (at paras 23-24) that it was, because once it was accepted that CA 1998, s 49 was wide enough to cover the strike-out of a follow-on claim, it was 'hard to identify any linguistic or policy barrier' to an opposite finding in respect of decisions not to strike-out a claim. Also see the Court of Appeal's analysis of the Enron case in: Walter Hugh Merricks CBE v Mastercard (fn 42), paras 23-28.

52 Walter Hugh Merricks CBE v Mastercard (CAT) (fn 14)

53 See CAT Rules 2015, Rule 79(2)(f), which provides that the suitability of the claims for an award of aggregate damages is one of the factors that the
CAT must take into account in determining whether the claims are suitable to be brought in collective proceedings.

54 Walter Hugh Merricks CBE v Mastercard (CAT) (fn 14), para 78. In reaching this conclusion, the CAT referred to the decision of the Canadian Supreme Court in Pro-Sys Consultants Ltd v Microsoft Corp. [2013] SCC 57 ('Microsoft'), para 118, which stated that: '[T] he expert methodology must be sufficiently credible or plausible to establish some basis in fact for the commonality requirement. This means that the methodology must offer a realistic prospect of establishing loss on a class-wide basis so that, if the overcharge is eventually established at the trial of the common issues, there is a means by which to demonstrate that it is common to the class (i.e. that passing on has occurred). The methodology cannot be purely theoretical or hypothetical, but must be grounded in the facts of the particular case in question. There must be some evidence of the availability of the data to which the methodology is to be applied.'

55 As required by CAT Rules 2015, Rule 79(1)(c).

56 Walter Hugh Merricks CBE v Mastercard (CAT) (fn 14), paras 88-89. The distribution method proposed by Mr Merricks was, in broad terms, that the aggregate loss for each of the 16 years in the claims period would be divided on an equal, per capita basis among the members of the class for that year (which would essentially be anyone resident in the UK and over the age of 16 in that year): see e.g. Walter Hugh Merricks CBE v Mastercard (CAT) (fn 14), paras 46-47. 
and those pass-on rates would vary geographically and over the 16-year duration of a claim period that began in $1992 .{ }^{57}$ Secondly, as regards distribution to individual class members, the CAT accepted that a 'top-down' methodology may in theory be permissible and that compensation to individuals will often be imprecise and broad-brush, ${ }^{58}$ but was concerned that the proposed method of distribution would have resulted in payments to individual class members that bore no relationship at all to how much loss they might actually have suffered (and in that sense did not even attempt to apply a 'broad axe' to the losses that may have been suffered by each class member). ${ }^{59}$ These key concerns of the CAT were a corollary of the phenomenal breadth of the proposed class and the absence of any proposal by Mr Merricks to account for the diversity of consumers and transactions contained within it. In that sense, at least, the fundamental concerns expressed by the CAT were specific to the facts of Merricks.

Mr Merricks appealed to the Court of Appeal on points of law. In April 2019, the Court of Appeal set aside the CAT's refusal to certify the proceedings and remitted the application back to the CAT for it to apply what the Court of Appeal considered to be the correct legal approach. ${ }^{60}$ In doing so, the Court of Appeal held that: (i) the CAT was wrong to have exposed the certification application to a more vigorous process of examination than would have taken place on a strike-out application (that is, to require Mr Merricks to demonstrate more than that he had a 'real prospect of success'); ${ }^{61}$ and (ii) it was premature and wrong for the CAT to have refused certification by reference to the proposed distribution method (and that error in law was compounded by the CAT proceeding on the basis that such distribution must be capable of being carried out by some means which corresponds to the individual losses of class members). ${ }^{62}$

57 Ibid, paras 77-78

58 Walter Hugh Merricks CBE v Mastercard (CAT) (fn 14), paras 67 and 88.

59 Ibid, paras 84 and 88.

60 Walter Hugh Merricks CBE v Mastercard (Court of Appeal) (fn 15).

61 Ibid, paras 53-54.

62 Ibid, para 62.

63 See fn 16 above.

64 See e.g. the government's response to a consultation on options for reform in private competition law actions: Department for Business Innovation \& Skills ('DBIS'), 'Private Actions in Competition Law: A consultation on options for reform - government response' (January 2013) (available at https://www.gov. uk/government/consultations/private-actions-in-competition-law-a-consul tation-on-options-for-reform), p 4, which states that: 'These are significant reforms that will dramatically increase the ability of business and consumers to hold to account those who have breached competition law'.

65 See e.g. the responses to the DBIS consultation on options for reform (fn 64) submitted by the Law Society of England and Wales and by the International Chamber of Commerce UK, available at: https://assets.publishing.service.
Mastercard sought, and in July 2019 was granted, permission to appeal to the Supreme Court. ${ }^{63}$ Some of the issues that arise from the Court of Appeal's judgment, and that will need to be considered by the Supreme Court to a greater or lesser extent, are summarized in Sections 3.2 to 3.4 below.

\subsection{The legal test for certification}

The collective proceedings regime that was introduced in the UK in 2015 was intended to enable more effective collective redress for businesses and consumers in competition cases. ${ }^{64}$ At the same time, however, there was an intention to ensure that the excesses of US class action regimes would be avoided and that proposed class actions would be subject to appropriately robust scrutiny before businesses were exposed to lengthy and potentially costly and reputationally-damaging class action litigation. ${ }^{65}$ The government therefore decided, amongst other things, that 'strong safeguards are critically important to an opt-out collective actions regime', ${ }^{66}$ one such safeguard being a 'strong process of judicial certification, including ... a requirement that a collective application must be the best way of bringing the case' ${ }^{37}$ A specific statutory scheme for certification of collective proceedings by the CAT was therefore established, pursuant to which collective proceedings could not be brought as of right and the CAT was afforded a broad discretion in deciding whether or not to certify proposed collective proceedings.

The correct legal approach to certification of collective proceedings must be considered in that policy and legislative context. When the Court of Appeal considered the legal approach to certification, it agreed that the CAT was entitled to make an assessment as to whether there was, or was likely to be, data available to operate the experts' proposed methodology for establishing loss on a class-wide basis. ${ }^{68}$ However, in the Court of Appeal's

gov.uk/government/uploads/system/uploads/attachment_data/file/69135/ private-actions-in-competition-law-a-consultation-on-options-for-reformresponses-g-to-n.pdf.

66 Government's response to the DBIS consultation (fn 64), para 5.53

67 Government's response to the DBIS consultation (fn 64), para 5.55.

68 Walter Hugh Merricks CBE v Mastercard (Court of Appeal) (fn 15), para 44. In this regard, the Court of Appeal, at para 40, agreed with the CAT that the test set out by the Supreme Court of Canada in Microsoft (fn 54) was appropriate. The Court of Appeal observed that although the Canadian jurisprudence was 'clearly' not binding on the CAT or the Court of Appeal, it 'provide[s] perhaps the most useful and proximate model for the UK regime' and accordingly 'the CAT was right to treat the Canadian jurisprudence on certification as informing the correct approach'. The Court of Appeal therefore appeared to agree that, as a matter of law (to which its jurisdiction was limited), Canadian jurisprudence was not binding on the CAT or the Court of Appeal, and accordingly that the approach to be applied to an application for a collective proceedings order under CA 1998 is a question of English law. 
view, the CAT had applied 'some form of mini trial' when making that assessment, ${ }^{69}$ and thereby erroneously exposed the claim to a higher standard of review than would apply on a strike-out application. ${ }^{70}$ The Court of Appeal concluded, to that extent, that: '[a] certification hearing is no different from any other interlocutory assessment of the prospects of success in litigation made before the completion of disclosure and the filing of evidence'. ${ }^{71}$

This reasoning raises critical issues for consideration by the Supreme Court. Those issues include not only whether the Court of Appeal correctly identified any reviewable errors of law in the judgment of the CAT (as opposed to disagreeing with the CAT's assessment of whether, in the words of the Supreme Court of Canada in Microsoft, there was a 'realistic prospect' of establishing loss on a class wide basis and evidence of the availability of data), ${ }^{72}$ but also broader issues under English law about the relationship between the 'strike-out' standard in ordinary civil litigation and the standard for 'certification' under the new collective actions regime.

In particular, the Supreme Court to will need interpret the statutory scheme for certification of collective proceedings by the CAT that is separate, and additional, to the possibility of strike-out or other interlocutory applications by a defendant, ${ }^{73}$ including in collective proceedings. ${ }^{74}$ That separate statutory scheme provides that collective proceedings cannot be brought as of right, and rather may continue only if the CAT 'considers that', ${ }^{75}$ and indeed is 'satisfied by the proposed class representative that', ${ }^{76}$ the claims are suitable to be brought collectively. In this way, the legislation imposes on the CAT an obligation to reach its own view on an application for a collective proceedings order and to be satisfied by the proposed class representative that the action is suitable to proceed. That appears, on its face, to be quite a different inquiry to the one that the CAT would be required to undertake should a defendant to a proposed collective action apply to strike it out, ${ }^{77}$ particularly given the well-established difficulty faced by defendants in sustaining a strike-out application in competition litigation. ${ }^{78}$

Similarly, the Supreme Court will need to consider the interaction between the 'real prospect of success' threshold that was set down by the Court of Appeal ${ }^{79}$ and the wide range of factors other than the underlying merits of the individual claims that the CAT is required to consider as part of its gatekeeping function under the relevant legislation. At the certification stage, the CAT is concerned not merely with the substantive merits of the claim (as it would be in a strike out application), ${ }^{80}$ but also with a host of other issues such as the appropriateness of the
69 Walter Hugh Merricks CBE v Mastercard (Court of Appeal) (fn 15), para 52.

70 Ibid, para 53. The Court of Appeal therefore stated, at para 54, that the CAT's approach to expert evidence: 'was based on a misdirection as to the correct test to be applied in relation to whether the proposed representative had demonstrated that the claims were suitable for inclusion in collective proceedings ....'

71 Walter Hugh Merricks CBE v Mastercard (Court of Appeal) (fn 15), para 44. Notwithstanding the policy background outlined above, the Court of Appeal also appeared to disagree with the CAT's 'self-direction' that it was required to 'scrutinise applications for a collective proceedings order with particular care, to ensure that only appropriate cases go forward': see Walter Hugh Merricks CBE v Mastercard (Court of Appeal) (fn 15), para 53, referring to Walter Hugh Merricks CBE v Mastercard (CAT) (fn 14), para 57. This was in the context of the Court of Appeal's view that a decision that the proposed representative is unable to access sufficient data is a decision which is 'much more appropriate to be taken once the pleadings, disclosure and expert evidence are complete and the Court is dealing with reality rather than conjecture', on the basis that 'certification is a continuing process under which a CPO may be varied or revoked at any time'. It is submitted that, as a matter of both law and policy, the possible revocation of a collective proceedings order is not a substitute for effective scrutiny by the CAT at the outset: the CAT has an obligation only to make such an order in the first place if it considers that the statutory pre-conditions are satisfied.

72 See Walter Hugh Merricks CBE v Mastercard (CAT) (fn 14), at paras 58 59, referring to the Canadian Supreme Court decision in Microsoft (fn 54), para 118.

73 CAT Rules 2015, Rule 41.

74 CAT Rules 2015, Rules 41 and 79(4)(a).

75 CA 1998, s 47B(6).

76 CAT Rules 2015, Rule 79(1).
77 Noting that any strike out application in collective proceedings is able to be heard by the CAT at the same time as, or after, the certification hearing: see CAT Rules 2015, Rule 79(4).

78 In particular, the English courts have recognized that anti-competitive conduct is typically (although not always) secret in nature, rendering it difficult to assess the strength of a claim prior to disclosure. The English courts are therefore reluctant to strike-out such claims before disclosure has taken place. See e.g. KME Yorkshire Limited v Toshiba Carrier UK Ltd [2012] Civ 1190, para 32 (where the Court of Appeal explained that: 'As was stated by the Court of Appeal in Cooper Tire \& Rubber Company Europe Ltd $v$ Dow Deutschland Inc [2010] EWCA Civ $864 \ldots$ it is in the nature of anti-competitive arrangements that they are shrouded in secrecy and so it is difficult until after disclosure of documents fairly to assess the strength or otherwise of [the claim] ... That same generous approach was for the same reason taken by Sales J in Nokia Corporation $v$ AU Optronics Corporation [2012] EWHC 731 in dismissing an application to strike-out or to grant summary judgment against the claimant in proceedings for damages for infringement of Article 101. That approach is appropriate in the present case prior to disclosure of documents'); and Bord Na Mona Horticulture Ltd $v$ British Polythene Industries Plc [2012] EWHC 3346 (Comm), para 30 (where the High Court stated that: 'where the claim involves damages arising out of infringements of competition law by cartels which by their nature are clandestine and the court is considering an application by an alleged participant in the cartel to strike-out a claim prior to disclosure and evidence, the court will tend to allow a more generous ambit for pleadings, where what is being alleged is necessarily a matter which is largely within the exclusive knowledge of defendants, than it might in other cases').

79 Walter Hugh Merricks CBE v Mastercard (Court of Appeal) (fn 15), paras 44 and 54.

80 Although it may consider them, particularly when considering whether proceedings should be opt-in or opt-out: see CAT Rules 2015, Rule 79(3)(a). The CAT Guide 2015, para 6.39, notes in this respect that: 'where the claims 
class representative, ${ }^{81}$ whether the claims raise common issues $^{82}$ and whether they are suitable to be brought in collective proceedings. ${ }^{83}$ As part of the latter 'suitability' assessment, the CAT is required to take account of 'all matters it thinks fit ${ }^{3}{ }^{84}$ including not only the suitability of an award of aggregate damages, ${ }^{85}$ but also other factors such as whether collective proceedings are an appropriate means for the fair and efficient resolution of the common issues, ${ }^{86}$ the costs and benefits of continuing the collective proceedings ${ }^{87}$ and the size and nature of the proposed class. ${ }^{88}$ It is submitted that this broad substantive content of the legislative gatekeeping was what led the CAT to observe that: 'the Applicant has to do more than simply show that he has an arguable case on the pleadings, as if, for example, he was facing an application to strike out'. 89

In its judgment, the Court of Appeal observes that none of those other factors enumerated in the CAT Rules 2015 require the CAT to be satisfied that the collective action has more than a 'real prospect of success'..$^{90}$ However, many of those factors do not concern the general merits of the claim at all, ${ }^{91}$ but are instead concerned with an assessment by the CAT of the suitability and practicability of the claims proceeding collectively (that is, of the claims being grouped together in accordance with the collective procedure). That appears to have been precisely the assessment that was undertaken by the CAT in deciding that it was not appropriate for Mr Merricks' proposed collective action to continue and, in particular, that the proceedings were not suitable for an aggregate award of damages (given, amongst other things, the extreme variation in the levels of pass-on that the CAT considered would apply as between different transactions and over time) ${ }^{92}$ That was, in the authors' opinion, an approach that the CAT was entitled to take, as a matter both of statutory construction and underlying policy.

Whether the Supreme Court agrees with the CAT or the Court of Appeal as regards the correct legal approach to certification could have significant implications for the ability of the CAT to refuse to certify actions that it does not consider to be suitable to be heard collectively. That will, in turn, help to determine whether the certification procedure operates in the manner that was envisaged by the government and lawmakers when the collective proceedings regime was introduced in 2015 , or on a more limited basis.

\subsection{Consideration of distribution issues}

In an extremely broad finding, the Court of Appeal held that the CAT had erred in law by considering any issues of distribution to individual class members at the certification stage. ${ }^{93}$ That was, in effect, a finding that issues of distribution are an irrelevant consideration, in an administrative law sense, at the certification stage of proposed collective proceedings. The CAT, on the other hand, was of the view that its discretion to take into account 'all matters it thinks fit' when assessing the suitability of claims for collective proceedings enabled it to consider Mr Merricks' proposals for how any aggregate award of damages would be distributed to class members before certifying a $£ 14$ billion claim. ${ }^{94}$

Which of those views the Supreme Court prefers when it considers the issue next year will determine the ability of the CAT to refuse certification of class actions that it considers may lead to insuperable difficulties in distributing any eventual award to represented class members. It could also have broader implications for the ability of the CAT to refuse to certify proposed actions that it considers to be unmeritorious and impracticable, having regard to the full range of factors that it considers to be relevant to the application before it (but which may not have arisen on the facts of any previous certification applications that it has considered).

The Court of Appeal also found that the CAT compounded its error of considering distribution at the certification stage at all by proceeding on the basis that such distribution to class members must be done in accordance with the ordinary tort principles of compensation. ${ }^{95}$ In Merricks the CAT had, in fact, accepted that a 'topdown' methodology may in theory be permissible seek damages for the consequence of an infringement which is covered by a decision of a competition authority (follow-on claims), they will generally be of sufficient strength for the purpose of this criteria'

81 CAT Rules 2015, Rules 77(1)(a) and 78

82 Ibid, Rules 77(1)(b) and 79(1)(b).

83 Ibid, Rules 77(1)(b) and 79(1)(c).

84 Ibid, Rule 79(2).

85 Ibid, Rule 79(2)(f).

86 Ibid, Rule 79(2)(a)

87 Ibid, Rule 79(2)(b)

88 Ibid, Rule 79(2)(d).

89 See Walter Hugh Merricks CBE v Mastercard (CAT) (fn 14), para 57.
90 Walter Hugh Merricks CBE v Mastercard (Court of Appeal) (fn 15), para 44.

91 These include, for example, the fundamental issues of causation that arise in the Merricks proceedings (see fn 120 below), but were not considered by the CAT at the certification stage.

92 Walter Hugh Merricks CBE v Mastercard (CAT) (fn 14), paras 57 and 77-78.

93 Walter Hugh Merricks CBE v Mastercard (Court of Appeal) (fn 15), at para 62.

94 See e.g. Walter Hugh Merricks CBE v Mastercard (CAT) (fn 14), paras 88-89.

95 Walter Hugh Merricks CBE v Mastercard (Court of Appeal) (fn 15), para 62. 
and that compensation to individuals will often be imprecise and based on broad estimates, ${ }^{96}$ but found that the proposed method of distribution to individual class members in that case bore no relation at all to the principle of compensation and it was impossible to see how the payments to individuals could be determined 'on any reasonable basis ${ }^{97}$ On appeal, the Supreme Court will be called upon to consider not only whether the CAT did in fact proceed on the basis that distribution to class members must be compensatory (which is a question of interpretation of the CAT's judgment), but also the broader (and potentially more important) question of whether it was legally open to the CAT to have regard to the absence of any connection between the proposed method of distribution and any losses that may actually have been suffered by individual class members. Consideration of these issues will, in turn, require interpretation by the Supreme Court of the power given to the CAT under the legislative scheme to make 'aggregate' awards of damages in collective proceedings, ${ }^{98}$ and in particular whether the possibility of awards that are compensatory on an aggregate basis displaces or precludes any reference or consideration being had by the CAT to ordinary English principles of tort law as regards potential damages that are ultimately to be received by class members whose individual claims are sought to be combined in collective proceedings. ${ }^{99}$ The latter would, it is submitted, be a fundamental point of English law to have been implemented without any express indication in the relevant policy or legislative materials. ${ }^{100}$

\subsection{Interpretation of the 'commonality' requirement}

The 'commonality' requirement for certification of collective proceedings was not a determinative factor in either the CAT's or the Court of Appeal's judgments. It is therefore unlikely to receive significant direct attention in the Supreme Court appeal.

The CAT and the Court of Appeal judgments did, however, provide somewhat differing indications of what they considered might amount to a 'common' issue in collective proceedings. The CAT, for example, indicated that the variations in pass-on between claims (as outlined above) were so great that pass-on to consumers could not be described as a common issue in any meaningful sense'. ${ }^{101}$ However, the CAT held that the commonality requirement in the legislation was still met because, unlike in the US, there is 'no requirement ... that the common issues should predominate over the individual issues'. ${ }^{102}$ The Court of Appeal, on the other hand, suggested that the issue of pass-on to consumers was a common issue, and therefore the statutory commonality requirement was met, because 'the issue of whether the MIF overcharge was passed-on to consumers generally and in what amounts is an issue common to all such individual claims as a necessary step in establishing loss by the class as a whole'. ${ }^{103}$ In simplified terms, therefore, as regards the issue of pass-on, the CAT asked itself whether there would be a common answer, while the Court of Appeal asked whether there was a common question.

Because these points were not dispositive of either judgment, the judgment of the Supreme Court in Merricks is unlikely to provide authoritative guidance on the commonality issue. Some points arising from the CAT and Court of Appeal judgments do, however, warrant brief mention at this stage. First, it must logically be the case that commonality is a statutory requirement to be met in respect of the individual underlying claims, rather than one that can be met simply by assuming first that the claims will be heard collectively and/or be the subject
96 Walter Hugh Merricks CBE v Mastercard (CAT) (fn 14), paras 67 and 88.

97 Walter Hugh Merricks CBE v Mastercard (CAT) (fn 14), paras 88-89.

98 See CA 1998, s 47C(2) ('The Tribunal may make an award of damages in collective proceedings without undertaking an assessment of the amount of damages recoverable in respect of the claim of each represented person'); and CAT Rules 2015, Rules 73(2) and 92. Neither the CA 1998 nor the CAT Rules 2015 establish any substantive principles by which the CAT is to determine the amount of damages to be awarded to the individual members of the class.

99 See e.g. Walter Hugh Merricks CBE v Mastercard (Court of Appeal) (fn 15), para 61, where the Court of Appeal states that: 'once the assessment of the aggregate award is complete then, on one view, Mastercard has no locus to be heard on the question of distribution and no right to object if the class members ... stand to be compensated in a way which does not exactly or perhaps even approximately replicate the individual losses which have been suffered. The vindication of the rights of individual claimants is achieved by the aggregate award itself. It is suggested that the Court of Appeal's references to Mastercard's 'locus to be heard' and 'right to object' in this paragraph are symptomatic of its broader view of the certification process as akin to a strike-out procedure, rather than a process whereby the CAT must be satisfied, by the proposed class representative, that the claims are suitable to be heard collectively. Although a Respondent will of course be entitled to make representations in the certification process, it is ultimately for the CAT to be satisfied by the proposed class representative that the claims are suitable to be brought collectively.

100 Also see Walter Hugh Merricks CBE v Mastercard (Court of Appeal) (fn 15), para 61, where the Court of Appeal stated that: '[c]laimants in this class will know that they stand to be compensated (if at all) on a per capita basis and can choose (if they wish) not to be included in the action'. However, as noted by the CAT, under Mr Merricks' proposed method of distribution: 'if, hypothetically, a million people opted out of the proceedings, there would be no proper way of reducing the quantum of damages accordingly': see Walter Hugh Merricks CBE $v$ Mastercard (CAT) (fn 14), para 87. That difficulty risks, in turn, re-introducing complex issues of potential aggregate over-compensation.

101 Walter Hugh Merricks CBE v Mastercard (CAT) (fn 14), para 66.

102 Ibid, para 67.

103 Walter Hugh Merricks CBE v Mastercard (Court of Appeal) (fn 15), para 46. 
of an aggregate award of damages and deducing the necessary commonality from that procedural mechanism. ${ }^{104}$ Secondly, the 'common question' formulation of the Court of Appeal could risk, if applied in future cases, essentially rendering the commonality requirement for certification illusory (given the core high-level issues, such as overcharge and pass-on, that are likely to arise in all competition damages claims). ${ }^{105}$

\section{Taking stock}

The issues that the Supreme Court will be called upon to consider in Merricks will clearly be fundamental to the certification of proposed collective proceedings. Although, as noted above, the refusal by the CAT to certify the Merricks proceedings was based on factors that were largely specific to that claim and its phenomenal breadth, the grounds upon which the Court of Appeal granted Mr Merricks' appeal raise issues of general and fundamental application to future proposed collective proceedings. This is particularly as regards the interaction (if any) between the thresholds for strike-out and certification and the factors that the CAT is entitled (and, perhaps more importantly, is not entitled) to have regard to at the certification stage when exercising its broad discretion under the new regime.

It is, nevertheless, important to bear in mind that the Supreme Court in Merricks will not consider and determine all points of law regarding the certification procedure under the new collective proceedings regime. Perhaps most notably, as explained in Section 3.4 above, the Court of Appeal's judgment in Merricks paid only cursory attention to the 'commonality' requirement for certification, and that issue is therefore unlikely to be a focus of the Supreme Court's attention. ${ }^{106}$ Similarly, in Merricks the Supreme Court will not address any issues of general application regarding the appropriateness of the class representative or his original funding arrangements, ${ }^{107}$ nor will it be called upon to deal with myriad other issues that will likely arise in future certification hearings, such as the detailed interpretation and definition of the other factors referred to in Rule 79(2) of the CAT Rules $2015,{ }^{108}$ how and when common issues and subclasses are defined ${ }^{109}$ and potential conflicts between class members. ${ }^{110}$ Many of those further issues will, it is submitted, remain ripe for consideration by the appellate courts (including, in appropriate cases, the Supreme Court) in the years to come and some such issues may even arise in the Merricks proceedings themselves should they be remitted to the CAT following consideration by the Supreme Court. The evolution of the case law and practice of the CAT and the appellate courts in respect of the certification procedure under the new regime is, therefore, likely to remain iterative and cumulative, even once welcome guidance from the Supreme Court in Merricks has been provided.

More broadly, it is essential to place the developments to date in the wider context of the collective proceedings regime. Those developments have been concerned exclusively with the certification of proposed collective proceedings. Attention will, eventually and in appropriate cases, need to turn to other aspects of the new collective proceedings regime. Those other aspects include matters such as case management of collective proceedings, ${ }^{111}$ the management of conflicts between class members, ${ }^{112}$ disclosure issues (including potentially from class members or third parties), ${ }^{113}$ potential split trials of common and individual issues, ${ }^{114}$ and potential collective
104 As held, for example, by the CAT in respect of volume of commerce in Merricks: see e.g. the transcript of day 2 of the certification hearing in Merricks on 19 January 2017 (available at https://www.catribunal.org.uk/sites/ default/files/1266_Walter_hugh_Transcript__Hearing_2_190117.pdf), p 68, lines 21-24.

105 For example, the list of issues that it is necessary for parties to produce in regular follow-on competition damages claims in the English High Court will almost always include issues of value of commerce, the existence of overcharge and pass-on, and interest, amongst other things.

106 Walter Hugh Merricks CBE v Mastercard (Court of Appeal) (fn 15), paras 46-47. Issues of commonality are likely to be very significant to the certification procedure in other proposed collective proceedings that are currently before the CAT, including in Trucks, Rail Fares and Forex. Those issues will likely include consideration by the CAT of the extent to which differences amongst claimants in such cases can and/or should be dealt with by the creation of sub-classes (and, if so, when those subclasses must or should be created), or are so great as to render claims unsuitable for collective proceedings. The CAT's (and appellate courts') position on these issues is likely to have significant implications for the future operation of the regime.

$107 \mathrm{Mr}$ Merricks has new third party funding arrangements in place, which will need to be examined by the CAT in the event that the case is ultimately remitted to it.
108 Such as whether collective proceedings are an appropriate means for the fair and efficient resolution of the common issues, the costs and benefits of continuing the collective proceedings, and the size and nature of the class: see Section 3.2 above.

109 For example, the CAT Rules 2015 require a collective proceedings claim form to contain, among other things, a description of any possible subclasses (Rule 75(3)(b)) and a list of 'common issues' raised by the claims (see Rules 73(2), 75(3)(e) and 79(1)(b)). Also see fn 82 and Section 3.4 above.

110 See e.g. CAT Guide 2015 (fn 33), para 6.35, which states that the use of sub-classes 'may be appropriate where there is a potential conflict between the interests of members of the broader class'.

111 CAT Rules 2015, Rule 88.

112 See above (fn 110) and CAT Guide 2015 (fn 33), para 6.35

113 CAT Rules 2015, Rule 89.

114 See e.g. CAT Rules 2015, Rules 74(6) and 88(2)(c) and CAT Guide 2015 (fn 33), paras 6.4 and 6.37, which envisage that individual issues (i.e. issues that are relevant only to certain represented persons) may be heard and determined either: (i) within the collective proceedings, but separately to the common issues; or (ii) following conclusion of the collective proceedings, with the claims proceeding thereafter as individual claims. 
settlements and/or collective redress schemes. ${ }^{115}$ Although there is a tendency (perhaps naturally) at this stage to treat the certification procedure as tantamount to the collective proceedings regime itself, it is important to acknowledge that many aspects of the regime will remain uncertain even once the fundamentals of the certification process are clarified by the Supreme Court in Merricks and in further decisions of the CAT and appellate courts. Many of those other, non-certification aspects of the new regime will also eventually be subject to scrutiny by the appellate courts. Again, the evolution of the regime will necessarily remain iterative and cumulative, as has been the case for other, longer-established class or group action regimes such as those in North America and Australia.

Overall, therefore, it is important to recognize that the Supreme Court will not, in Merricks, itself determine whether those proceedings should be certified, the merits of the underlying claims ${ }^{116}$ or many other important questions of English law regarding the new regime that will need to be considered and determined by the CAT and the appellate courts over the coming years. Having said that, there is no question that the Supreme Court appeal in Merricks will address issues that are critical to the certification procedure and will be of significant importance to the early development of the 2015 regime for competition class actions, building on the existing developments that have taken place in the case law and practice of the CAT over the past four years.

\section{Conclusion}

It is submitted that the most important determinant of the long-term success of the new collective proceedings regime will be whether sound and balanced legal and policy settings are established early in the development of the regime in order to set it on an efficient and principled trajectory. The UK therefore can, and should, aim for more than simply any legal approach that gets the regime 'off the ground' regardless of the suitability of the proposed proceedings. The aim, rather, should be for a high quality and efficient regime where only suitable cases proceed. The risk, otherwise, is that anomalous cases make bad law that will burden the regime in the years and decades to come.

Having gained some welcome clarity and predictability on many aspects of the certification procedure under the new collective proceedings regime over the past four years, and with an authoritative judgment by the Supreme Court on more substantive matters regarding certification likely to be received during the course of 2020 , the regime ought to be on a strong footing once it resumes. In the meantime, the continued appetite for such proceedings to be brought (most recently in respect of foreign exchange fees) only reinforces the need for strong and principled foundations - particularly regarding the important gatekeeping role of the CAT at the certification stage of proposed collective proceedings to be set before the regime bounds forward apace.
115 CAT Rules 2015, Rules 94-97.

116 The vast majority of Mr Merricks' claim relies, for example, on establishing a connection between certain European fees that were the subject of a decision by the European Commission in 2007, and domestic UK fees that were not considered by the European Commission and set separately. The credibility of that position - and of some issues concerning the age of the claims, the earliest of which date back to 1992 - will need to be tested by the CAT at an early stage of the litigation, should it proceed. 